\title{
Biological Control of Onion White Rot Disease using Bacillus spp. Isolated from Egyptian Soil
}

A.A. Abd-Elbaky*; Abeer M. Shaltout*; N.Y. AbdEl-Ghafar** and M.S. Abd El-Magid*

* Plant Pathol. Res. Inst., A.R.C., Giza, Egypt.

** Plant Pathol. Dept. ,Fac. Agric., Ain Shams Univ., Egypt.

\begin{abstract}
The antagonistic ability of eleven bacterial isolates against Sclerotium cepivorum, causal agent of onion white rot disease (OWR), was determined in vitro and the best five isolates were identified as Bacillus pumilus $\left(\mathrm{BP}_{1}\right.$ and $\left.\mathrm{BP}_{2}\right)$ and B. marinus $\left(\mathrm{BM}_{1}\right.$, $\mathrm{BM}_{2}$ and $\mathrm{BM}_{3}$ ). The in vitro antagonistic efficacy ranged between 11.1 to $68.9 \%$ depending on the concentration of the bacterial cell suspension and number of applied sprays under greenhouse and field conditions. It was found that using double sprays with B. pumilus $\left(\mathrm{BP}_{2}\right)$ in the greenhouse experiment gave the highest efficacy in reducing OWR (93.8\%) at the concentrations of 10 and $20 \mathrm{ml} / \mathrm{l}$. In case of field experiment there was no significant deference between number of sprays or the tested bacteria in reducing infection percentage of OWR. The significant difference was reported only between the concentrations of the bacterial suspension during the two growing seasons 2008/2009 - 2009/2010. In case of using one spray during season 2008/2009, the most effective bacteria in reducing OWR was $B$. pumilus $\left(\mathrm{BP}_{2}\right)$ giving 64.7 and $61.6 \%$ efficacy when used at the concentrations $20 \mathrm{ml} / 1$ and $10 \mathrm{ml} / 1$, respectively, followed by $B$. marinus $\left(\mathrm{BM}_{3}\right)$ which gave $58.2 \%$ at the concentration $20 \mathrm{ml} / 1$. On the other hand, when two sprays of bacterial suspension were used B. marinus $\left(\mathrm{BM}_{1}\right)$ and B. pumilus $\left(\mathrm{BP}_{1}\right)$ gave the highest efficacy in reducing OWR reached 63.7 and $63.4 \%$, respectively. During season $2009 / 2010$ B. pumilus $\left(\mathrm{BP}_{2}\right)$ was the most effective bacteria reached $80.0 \%$ efficacy followed by B. marinus $\left(\mathrm{BM}_{3}\right)$ recorded $76.9 \%$ when both used at the concentration $20 \mathrm{ml} / 1$ for one spray. When two sprays were used, B. marinus $\left(\mathrm{BM}_{2}\right)$ gave the highest percentage of efficacy in reducing OWR $(87.3 \%)$. Data showed that applying the tested bacteria at any concentration, either once or twice, significantly increased onion bulb yield compared with control treatment during the two growing seasons.
\end{abstract}

Keywords: Bacillus marinus, B. pumilus, Biological control and white rot.

Onion (Allium cepa L.) is an important crop in Egypt for local consumption and exportation. According to the Statistical Department of Ministry of Agriculture and Land Reclamation, the total bulb crop acreage was 125397 feddan yielded 1731824 tons in 2009/2010 (Anonymous, 2010). 
Onion white rot (OWR) disease, caused by Sclerotium cepivorum Berk., is a serious disease of onion and other Allium spp. in Egypt (Abd El-Moity, 1981 and Satour et al., 1992) as well as many other onion growing areas of the world (Crowe et al., 1980). Onion white rot disease affects the genus Allium and threatens Allium production in several parts of the world. For example, between 1965 and 1982 , white rot disease caused a $65 \%$ reduction in the production area of winter onions in Egypt, and a 90\% decrease in exports. The disease attacks the root system of host plants, resulting in either death before harvest or postharvest decay (Entwistle, 1990a). The pathogen survives in the soil as sclerotia and may remain dormant in this state in the absence of the host for 20 years (Coley-Smith, 1990).

A number of control methods have been researched including fungicide application (Stewart et al., 1994b and Khaled et al., 1997), soil fumigants (Entwistle, 1990b), soil solarization (Porter and Merriman, 1983, Melero-Vara et al., 2000) and use of biocontrol agents (Stewart et al., 1994a; Gevlagh et al., 1996 and Abd El-Magid and Abd El- Momen, 2008).

The continuous use of chemicals at high concentrations has developed pathogen fungicidal resistance and impacted nontarget species and the environment with potential public health concerns (De Weger et al., 1995 and Zhang et al., 2009). There is a growing need for alternative control measures that are environmental friendly for control of OWR disease. The use of microorganisms to control plant diseases is a promising strategy and has potential for managing OWR disease. Compared with chemical control, using microbial agents to control plant pathogens can be eco-friendly and cost-effective component of an integrated pest management (Mao et al., 1997).

Many Bacillus strains are known to suppress the in vitro fungal growth by the production of one or more antifungal antibiotics (Katz and Demain, 1977). Some of these antibiotics producing strains were also shown to suppress in vivo fungal plant diseases (Fravel, 1988).

Bacillus pumilus MA111M4a showed a strong inhibitory activity against the fungi Rhizoctonia solani, Pythium aphandermatum and Sclerotium rolfsii (Fálvia et al., 2009). Also, many authors investigated the ability of B. pumilus isolates to control other plant pathogenic fungi such as Rhizoctonia solani on rice (Padaria and Aqbal-Singh, 2009) root-rot disease complex of chickpea (Sayed and Siddiqui, 2008) as well as pathogenic bacterium Pseudomonas syringae pv. tomato on tomato (Silva et al., 2008). In other researches, an antifungal compound that is active against Mucoracea and Aspergillus species have been reported (Edward and Richard, 2003).

Several workers suggested B. marinus as a biocontrol agent. Odile et al. (2003) used it to control cucumber damping-off, also Gao et al. (2010) observed that tomato gray mould and early blight could be controlled using $B$. marinus.

The objective of this work is to determine the ability of two species of Bacillus, i.e. B. pumilus and B. marinus, to control onion white rot under greenhouse and field conditions. 


\section{Materials and Methods}

\section{1- The pathogen:}

An isolate of Sclerotium cepivorum used in this study was isolated from onion plants exhibiting typical symptoms of white rot disease. Infected samples were collected from Mallawi Agricultural Research Station, El-Minia Governorate. Isolated pathogen was purified and preserved, on potato dextrose agar (PDA), for subsequent studies.

2- Isolation and identification of the biocontrol agents:

Eleven bacterial isolates were collected from leaves of 90-day-old healthy onion plants (cv. Giza) grown in naturally field at Nobaria, Behera Governorate. The bacteria were isolated on nutrient agar (NA) medium and incubated at $27^{\circ} \mathrm{C}$. Cultures were kept under glycerol oil for farther studies. Identification of antagonistic bacterial isolates was made based on morphological, physiological and biochemical characteristics according to (Fahy and Persely, 1983; Lelliot and Stead, 1987 and Schaad, 1988).

3- Evaluation of antagonistic potential of bacteria against $S$. cepivorum:

Bacterial isolates were streaked on one side of PDA plates and incubated at $27^{\circ} \mathrm{C}$ for $24 \mathrm{hr}$. Discs $(0.5 \mathrm{~cm})$ of (4-day-old) $S$. cepivorum cultures were aseptically transferred into the bacterial plates, and incubated at $25^{\circ} \mathrm{C} \pm 2$ for 5 days. Plates of the tested fungus only were kept as check (control) treatment. Three plates were served as replicates for each treatment. The percentage of reduction in the radius growth of the fungus was calculated according to Fokkema (1973) as follows:

Reduction in linear growth $(\%)=\left(\mathrm{R}_{1}-\mathrm{R}_{2}\right) / \mathrm{R}_{1} \mathrm{X} 100$

Whereas: $\mathrm{R}_{1=}$ The radius of normal (control) growth .

$\mathrm{R}_{2}=$ The radius of inhibited growth.

4- Greenhouse evaluation of the tested bacterial antagonists:

Greenhouse experiment was conducted to evaluate the ability of Bacillus pumilus and B. marinus to control OWR. Sclerotium cepivorum inoculum was prepared by growing pure culture of the pathogen on sorghum - washed sand $(1: 1 \mathrm{v} / \mathrm{v})$ for 15 days at $27^{\circ} \mathrm{C}$, then used to infest sterilized soil at the rate $2 \%(\mathrm{w} / \mathrm{w})$ seven days before planting. Onion seedlings (cv. Giza 6) were dipped for 15 minutes in $25 \mathrm{ml}$ of the cell suspension $\left(2 \times 10^{7} \mathrm{cfu}\right)$ of each tested bacteria, amended with $(0.5 \mathrm{ml} / \mathrm{l})$ Arabic gum as adhesive material, before planting in pots $(25 \mathrm{~cm})$ containing the infested soil. Five seedlings were transplanted in each infested pots. Tested treatments were carried out as the following: A) one spray with each of the tested bacterial cell suspensions after 6 weeks from transplanting at the rate 5, 10 and $20 \mathrm{ml} / \mathrm{l}$. B) two sprays with the bacterial cell suspensions after 6 and 12 weeks from transplanting with the same former rates. Four pots served as replicates for each treatment as well as four untreated pots served as control. Disease incidence and infection percentage were calculated at the end of the growing season.

\section{5- Field experiment:}

Field experiment was carried out at Mallawi Research Station Farm, during 2008-2009 and 2009-2010 seasons, to evaluate the efficiency of the antagonistic 
bacterial isolates to control onion white rot (OWR) under naturally infested field conditions with $S$. cepivorum was chosen in this study. Split plot design was used where onion transplants were planted in $3.5 \times 3 \mathrm{~m}$ experimental plots. Two hundred onion seedlings were dipped in $100 \mathrm{ml}$ of the cell suspension of each of the tested antagonistic bacteria containing $2 \times 10^{7}$ cfu for 15 minutes and sprayed with the cell suspension of each of the antagonistic bacteria as mentioned before in the greenhouse experiment with same two treatments. Each treatment was replicated three times and three control plots were planted and left without bacterial treatment.

After 150 days from transplanting, percentage of infection with white rot disease as well as the yield of onion bulbs were estimated for each plot.

Statistical analysis:

In all experiments the least significance difference (LSD) at 0.05 confidences was determined according to Gomez and Gomez (1984).

\section{Res u l t s}

1- In vitro evaluation of bacterial antagonists:

Eleven isolates of the tested bacteria were used to investigate their ability to inhibit the mycelial growth of Sclerotium cepivorum. Data in Table (1) show that all the tested bacterial isolates significantly decreased the radial growth of the fungus compared with control treatment. The efficacy of antagonistic bacteria ranged between $11.1 \%$ to $68.9 \%$. The most antagonistic bacteria was the isolate (D) with efficacy $68.9 \%$ followed by isolates (B), (C) and (F) with $65.6,64.1$ and $64.1 \%$ efficacy, respectively.

Table 1. Antagonistic effect of some bacteria on the radial growth of Sclerotium cepivorum

\begin{tabular}{|c|c|c|}
\hline Tested bacteria & S. cepivorum mycelial growth $(\mathrm{cm})$ & Growth reduction (\%) \\
\hline A & 3.93 & 56.3 \\
\hline B & 3.10 & 65.6 \\
\hline C & 3.23 & 64.1 \\
\hline D & 2.80 & 68.9 \\
\hline E & 3.67 & 59.2 \\
\hline F & 3.23 & 64.1 \\
\hline G & 8.00 & 11.1 \\
\hline H & 3.60 & 60.0 \\
\hline I & 5.90 & 34.4 \\
\hline J & 5.10 & 43.3 \\
\hline K & 8.00 & 11.1 \\
\hline Control & 9.00 & 0.0 \\
\hline L.S.D at $1 \%$ & 1.7 & \\
\hline
\end{tabular}




\section{2- Identification of the isolated biocontrol agents:}

The most effective bacterial isolates in inhibiting $S$. cepivorum mycelial growth were identified according to cultural properties, morphological, physiological and biochemical characteristics. From identification tests it was revealed that isolates ( $\mathrm{B}$ and $\mathrm{F}$ ) belonged to Bacillus pumilus isolates $\mathrm{BP}_{1}$ and $\mathrm{BP}_{2}$, respectively. Meanwhile, isolates $(\mathrm{C}, \mathrm{D}$ and $\mathrm{H})$ belonged to $B$. marinus isolates $\mathrm{BM}_{1}, \mathrm{BM}_{2}$ and $\mathrm{BM}_{3}$, respectively.

\section{3- Greenhouse experiment:}

Data in Table (2) indicate that all the tested antagonistic bacteria significantly decreased the infection percentage of onion white rot (OWR) disease under greenhouse conditions. Bacillus pumilus (BP1) and B. marinus $\left(\mathrm{BM}_{3}\right)$ were the most effective ones since they recorded $68.8 \%$ efficacy of reducing OWR when one spray of $5 \mathrm{ml} / \mathrm{l}\left(2 \times 10^{7} \mathrm{cfu} / \mathrm{ml}\right)$ dose was used. It was found that using two sprays with the bacterial cell suspension was more efficient in reducing OWR disease compared with one spray application.

Table 2. Effect of some bacterial bioagents and their rates of application on incidence of OWR disease under greenhouse conditions

\begin{tabular}{|c|c|c|c|c|c|c|c|}
\hline \multirow{2}{*}{$\begin{array}{c}\text { Antagonistic } \\
\text { bacteria }\end{array}$} & \multirow{2}{*}{$\begin{array}{c}\text { No. of } \\
\text { applications }\end{array}$} & \multicolumn{3}{|c|}{ Infection $(\%)$ at } & \multicolumn{3}{|c|}{ Efficacy (\%) } \\
\hline & & $5 \mathrm{ml} / 1$ & $10 \mathrm{ml} / 1$ & $20 \mathrm{ml} / 1$ & $5 \mathrm{ml} / 1$ & $10 \mathrm{ml} / 1$ & $20 \mathrm{ml} / 1$ \\
\hline \multirow{2}{*}{$\begin{array}{l}\text { B. marinus } \\
\left(\mathrm{BM}_{1}\right)\end{array}$} & 1 & 65.0 & 60.0 & 70.0 & 18.8 & 25.0 & 12.5 \\
\hline & 2 & 55.0 & 20.0 & 60.0 & 31.3 & 75.0 & 25.0 \\
\hline \multirow{2}{*}{$\begin{array}{l}\text { B. marinus } \\
\left(\mathrm{BM}_{2}\right)\end{array}$} & 1 & 55.0 & 60.0 & 60.0 & 31.1 & 25.0 & 25.0 \\
\hline & 2 & 30.0 & 45.0 & 50.0 & 62.5 & 43.8 & 37.5 \\
\hline \multirow{2}{*}{$\begin{array}{l}\text { B. marinus } \\
\left(\mathrm{BM}_{3)}\right.\end{array}$} & 1 & 25.0 & 60.0 & 75.0 & 68.8 & 25.0 & 6.3 \\
\hline & 2 & 15.0 & 30.0 & 45.0 & 81.3 & 62.5 & 43.8 \\
\hline \multirow{2}{*}{$\begin{array}{l}\text { B. pumilus } \\
\left(\mathrm{BP}_{1}\right)\end{array}$} & 1 & 25.0 & 35.0 & 65.0 & 68.8 & 56.3 & 18.8 \\
\hline & 2 & 10.0 & 15.0 & 65.0 & 87.5 & 81.3 & 18.8 \\
\hline \multirow{2}{*}{$\begin{array}{l}\text { B. pumilus } \\
\left(\mathrm{BP}_{2}\right)\end{array}$} & 1 & 60.0 & 45.0 & 40.0 & 25.0 & 43.8 & 50.0 \\
\hline & 2 & 50.0 & 5.0 & 5.0 & 37.5 & 93.8 & 93.8 \\
\hline Control & 0 & 80.0 & 80.0 & 80.0 & 0.0 & 0.0 & 0.0 \\
\hline \multicolumn{8}{|l|}{ LSD at $1 \%$ for: } \\
\hline
\end{tabular}

Data also revealed that $B$. pumilus $\left(\mathrm{BP}_{2}\right)$ gave the highest efficacy $(93.8 \%)$ in reducing OWR when used as double spray at the concentrations 10 and $20 \mathrm{ml} / \mathrm{l}$. It was followed by $B$. pumilus $\left(\mathrm{BP}_{1}\right)$ which gave $87.5 \%$ efficacy when used at the concentration of $5 \mathrm{ml} / \mathrm{l}$. In this concern, Bacillus marinus $\left(\mathrm{BM}_{3}\right)$ recorded the lowest (6.3\%) efficacy when used as one spray at the concentration $20 \mathrm{ml} / \mathrm{l}$. Generally, in case of using one spray of bacterial cell suspension it was found that $5 \mathrm{ml} / 1$ concentration was the most effective one and $10 \mathrm{ml} / 1$ concentration was the best one when used as two sprays. 


\section{4- Field experiment:}

Five bacterial isolates were used to investigate their ability to control OWR disease with antagonistic potentials during two growing seasons (2008/2009 2009/2010). Data represented in Table (3) show the infection percentage of OWR and the efficiency of the tested bacteria to control it during the growing season $2008 / 2009$. The tested bacteria significantly reduced the infection percentage of OWR compared with control treatment. There was no significant deference at the isolate levels between numbers of sprays but the significant difference was found between the concentrations of the bacterial cell suspension. In case of using one spray, the most effective bacteria in reducing OWR was B. pumilus $\left(\mathrm{BP}_{2}\right)$ giving 64.7 and $61.6 \%$ efficacy when used at the concentrations $20 \mathrm{ml} / 1$ and $10 \mathrm{ml} / \mathrm{l}$, respectively, followed by $B$. marinus $\left(\mathrm{BM}_{3}\right)$ which gave $58.8 \%$ at the concentration $20 \mathrm{ml} / 1$. On the other hand, when two sprays of cell suspension were used B. marinus $\left(\mathrm{BM}_{1}\right)$ and $B$. pumilus $\left(\mathrm{BP}_{1}\right)$ gave the highest efficacy in reducing OWR when recorded 63.7 and $63.4 \%$, respectively.

Table 3. Effect of number and rate of application of bioagent bacteria on infection percentage with onion white rot and efficacy under field conditions at Mallawi during 2008-2009

\begin{tabular}{|c|c|c|c|c|c|c|c|}
\hline \multirow{2}{*}{ Antagonistic bacteria } & \multirow{2}{*}{$\begin{array}{c}\text { No. of } \\
\text { applications }\end{array}$} & \multicolumn{3}{|c|}{ Infection $(\%)$ at } & \multicolumn{3}{|c|}{ Efficacy (\%) } \\
\hline & & $5 \mathrm{ml} / 1$ & $10 \mathrm{ml} / 1$ & $20 \mathrm{ml} / 1$ & $5 \mathrm{ml} / 1$ & $10 \mathrm{ml} / \mathrm{l}$ & $20 \mathrm{ml} / 1$ \\
\hline \multirow{2}{*}{ B. marinus $\left(\mathrm{BM}_{1}\right)$} & 1 & 15.3 & 14.2 & 13.7 & 45.9 & 51.4 & 53.1 \\
\hline & 2 & 12.3 & 11.7 & 10.7 & 58.3 & 60.3 & 63.7 \\
\hline \multirow{2}{*}{ B. marinus $\left(\mathrm{BM}_{2}\right)$} & 1 & 15.8 & 15.3 & 14.7 & 45.9 & 47.6 & 49.7 \\
\hline & 2 & 15.2 & 14.2 & 12.3 & 48.5 & 51.9 & 58.3 \\
\hline \multirow{2}{*}{ B. marinus $\left(\mathrm{BM}_{3}\right)$} & 1 & 14.5 & 13.7 & 12.2 & 50.3 & 53.0 & 58.8 \\
\hline & 2 & 14.0 & 13.3 & 13.2 & 52.5 & 54.9 & 55.3 \\
\hline \multirow{2}{*}{ B. pumilus $\left(\mathrm{BP}_{1}\right)$} & 1 & 16.7 & 13.7 & 13.2 & 42.8 & 53.1 & 54.8 \\
\hline & 2 & 13.8 & 11.7 & 10.8 & 53.2 & 60.3 & 63.4 \\
\hline \multirow{2}{*}{ B. pumilus $\left(\mathrm{BP}_{2}\right)$} & 1 & 15.7 & 11.2 & 10.3 & 46.2 & 61.6 & 64.7 \\
\hline & 2 & 12.7 & 12.3 & 11.8 & 56.9 & 58.3 & 60.0 \\
\hline Control & - & 29.0 & 29.0 & 29.0 & 0.0 & 0.0 & 0.0 \\
\hline \multicolumn{8}{|c|}{$\begin{array}{ll}\text { LSD at } 5 \% \text { for: } & \text { Spray }(\mathrm{S})=\mathrm{NS} ; \\
& \mathrm{S} \times \mathrm{T}=2.47\end{array}$} \\
\hline
\end{tabular}

Similar trend was found in 2009/2010 (Table 4) since all the tested bacteria significantly reduced the infection percentages of OWR compared with the control treatment. Also, B. pumilus $\left(\mathrm{BP}_{2}\right)$ was the most effective bacteria giving $80.0 \%$ efficacy followed by $B$. marinus $\left(\mathrm{BM}_{3}\right)$ giving $76.9 \%$ when both used at the concentration $20 \mathrm{ml} / 1$ for one spray. When two sprays were used B. marinus $\left(\mathrm{BP}_{2}\right)$ gave the highest percentage of efficacy in reducing OWR $(87.3 \%)$ followed by B. pumilus $\left(\mathrm{BP}_{2}\right)$ and B. marinus $\left(\mathrm{BM}_{3}\right)$ giving 81.8 and $80.5 \%$, respectively, when it applied as two sprays at the concentration $20 \mathrm{ml} / 1$. 
Table 4. Effect of number and rate of application of bioagent bacteria on infection percentage with onion white rot and efficacy under field conditions at Mallawi Research Station during 2009-2010

\begin{tabular}{|c|c|c|c|c|c|c|c|}
\hline \multirow{2}{*}{ Antagonistic bacteria } & \multirow{2}{*}{$\begin{array}{l}\text { No. of } \\
\text { applications }\end{array}$} & \multicolumn{3}{|c|}{ Infection $(\%)$ at } & \multicolumn{3}{|c|}{ Efficacy (\%) } \\
\hline & & $5 \mathrm{ml} / 1$ & $10 \mathrm{ml} / 1$ & $20 \mathrm{ml} / \mathrm{l}$ & $5 \mathrm{ml} / 1$ & $10 \mathrm{ml} / 1$ & $20 \mathrm{ml} / 1$ \\
\hline \multirow{2}{*}{ B. marinus $\left(\mathrm{BM}_{1}\right)$} & 1 & 18.0 & 16.7 & 13.3 & 67.7 & 69.6 & 75.8 \\
\hline & 2 & 15.3 & 15.0 & 14.0 & 72.2 & 72.7 & 74.5 \\
\hline \multirow{2}{*}{ B. marinus $\left(\mathrm{BM}_{2}\right)$} & 1 & 16.3 & 13.7 & 13.3 & 70.4 & 75.1 & 75.8 \\
\hline & 2 & 14.3 & 9.3 & 7.0 & 74.0 & 83.1 & 87.3 \\
\hline \multirow{2}{*}{ B. marinus $\left(\mathrm{BM}_{3}\right)$} & 1 & 15.3 & 15.0 & 12.7 & 72.2 & 72.7 & 76.9 \\
\hline & 2 & 11.0 & 10.3 & 10.7 & 80.0 & 81.3 & 80.5 \\
\hline \multirow{2}{*}{ B. pumilus $\left(\mathrm{BP}_{1}\right)$} & 1 & 18.7 & 15.3 & 14.7 & 66.0 & 72.2 & 73.3 \\
\hline & 2 & 16.0 & 13.3 & 13.0 & 70.9 & 75.8 & 76.4 \\
\hline \multirow{2}{*}{ B. pumilus $\left(\mathrm{BP}_{2}\right)$} & 1 & 17.3 & 14.0 & 11.0 & 68.5 & 74.5 & 80.0 \\
\hline & 2 & 13.7 & 11.7 & 10.0 & 75.1 & 78.7 & 81.8 \\
\hline Control & 0 & 55.0 & 55.0 & 55.0 & 0.0 & 0.0 & 0.0 \\
\hline \multicolumn{8}{|c|}{$\begin{array}{ll}\text { LSD at } 5 \% \text { for: } & \text { Spray }(\mathrm{S})=\mathrm{NS} ; \quad \text { Treatment }(\mathrm{T})=0.72 ; \quad \text { Concentration }(\mathrm{C})=1.41 ; \\
& \mathrm{S} \times \mathrm{T}=1.01 ; \quad \mathrm{S} \times \mathrm{C}=2.00 ; \quad \mathrm{T} \times \mathrm{C}=3.16 ; \quad \mathrm{S} \times \mathrm{T} \times \mathrm{C}=4.47\end{array}$} \\
\hline
\end{tabular}

In general, the tested bacteria were more effective in reducing OWR disease in the second growing season compared with the first one. Also, using the concentration $20 \mathrm{ml} / 1$ gave the most efficacy wither it was sprayed once or twice.

\section{5- Effect of the biocontrol bacteria on the yield:}

Data represented in Table (5) indicate the effect of the tested bacteria, used in three concentrations and two application numbers, on onion yield during two growing seasons 2008-2009 and 2009-2010. Data show that applying the tested bacteria at any concentration either once or twice significantly increased onion bulb yield compared with control treatment during the two growing seasons. At the same time there were no significant difference between numbers of sprays or the tested bacteria or the reaction between sprays number but it was found between the concentrations. The most effective bacteria in increasing the bulbs yield in the growing season 2008/2009 was B. pumilus (BP2) giving $18.05 \mathrm{~kg}$ /plot when used at the concentration $20 \mathrm{ml} / \mathrm{l}$ as double sprays followed by B. marinus (BM2) giving $17.89 \mathrm{~kg} / \mathrm{plot}$ at same concentration and number of sprays. On the other hand, in the growing season 2009/2010 although bulb yield was lesser than the former season (even in the control treatment),the same trend was observed since no significant difference between number of sprays or the tested bacteria was found but it was also found between the concentrations. However, applying the tested bacteria significantly increased bulb yield compared with nontreated plants. B. marinus (BM3) was the most effective in increasing bulb yield giving $15.54 \mathrm{~kg} / \mathrm{plot}$ when used at $10 \mathrm{ml} / 1$ concentration for double sprays while giving $15.49 \mathrm{~kg} / \mathrm{plot}$ when applied at $10 \mathrm{ml} / / 1$ for one spray. B. pumilus (BP1) came secondly with $15.39 \mathrm{~kg} / \mathrm{plot}$ when it was sprayed twice at $20 \mathrm{ml} / \mathrm{l}$ concentration. 
Table 5. Effect of number of sprays and cell suspensions concentrations of antagonistic bacteria on weight of onion bulbs at 2008-2009 and 2009-2010 seasons

\begin{tabular}{|c|c|c|c|c|c|c|c|}
\hline \multirow{3}{*}{$\begin{array}{c}\text { Antagonistic } \\
\text { bacteria }\end{array}$} & \multirow{3}{*}{$\begin{array}{c}\text { No. of } \\
\text { applications }\end{array}$} & \multicolumn{6}{|c|}{ Weight of onion bulbs ( $\mathrm{kg} / \mathrm{plot})$ at seasons } \\
\hline & & \multicolumn{3}{|c|}{$2008-2009$} & \multicolumn{3}{|c|}{$2008-2009$} \\
\hline & & $5 \mathrm{ml} / 1$ & $10 \mathrm{ml} / 1$ & $20 \mathrm{ml} / 1$ & $5 \mathrm{ml} / 1$ & $10 \mathrm{ml} / 1$ & $20 \mathrm{ml} / 1$ \\
\hline \multirow[b]{2}{*}{ B. marinus $\left(\mathrm{BM}_{1}\right)$} & 1 & 15.82 & 16.64 & 16.67 & 12.22 & 12.85 & 14.00 \\
\hline & 2 & 16.40 & 17.53 & 17.88 & 12.67 & 13.11 & 13.56 \\
\hline \multirow[b]{2}{*}{ B. marinus $\left(\mathrm{BM}_{2}\right)$} & 1 & 16.31 & 16.65 & 16.98 & 12.14 & 12.91 & 14.18 \\
\hline & 2 & 16.80 & 16.89 & 17.89 & 13.48 & 13.56 & 13.82 \\
\hline \multirow{2}{*}{ B. marinus $\left(\mathrm{BM}_{3}\right)$} & 1 & 16.96 & 17.13 & 17.36 & 12.49 & 13.24 & 15.49 \\
\hline & 2 & 16.57 & 17.77 & 17.79 & 13.13 & 15.54 & 15.05 \\
\hline \multirow{2}{*}{ B. pumilus $\left(\mathrm{BP}_{1}\right)$} & 1 & 16.54 & 17.33 & 17.77 & 12.00 & 12.15 & 14.84 \\
\hline & 2 & 16.18 & 16.70 & 17.15 & 12.67 & 14.79 & 15.39 \\
\hline \multirow{2}{*}{ B. pumilus $\left(\mathrm{BP}_{2}\right)$} & 1 & 16.60 & 17.70 & 17.92 & 12.74 & 13.67 & 14.24 \\
\hline & 2 & 16.73 & 17.10 & 18.05 & 13.58 & 13.91 & 14.33 \\
\hline Control & 0 & \multicolumn{3}{|c|}{\begin{tabular}{|l|l|}
11.83 & 11.83 \\
\end{tabular}} & \multicolumn{2}{|l|}{9.67} & 9.67 \\
\hline \multicolumn{2}{|c|}{ LSD at $5 \%$ for } & \multicolumn{3}{|c|}{$\begin{array}{l}\text { Spray }(\mathrm{S})=\mathrm{NS} \\
\text { Bacteria }(\mathrm{B})=\mathrm{NS} \\
\text { Concentration }(\mathrm{C})=0.38 \\
\mathrm{~S} \times \mathrm{B}=\mathrm{NS} \\
\mathrm{S} \times \mathrm{C}=0.54 \\
\mathrm{~B} \times \mathrm{C}=0.85 \\
\mathrm{~S} \times \mathrm{B} \times \mathrm{C}=1.2\end{array}$} & \multicolumn{3}{|c|}{$\begin{array}{l}(\mathrm{S})=\mathrm{NS} \\
(\mathrm{B})=\mathrm{NS} \\
(\mathrm{C})=0.86 \\
\mathrm{~S} \times \mathrm{B}=\mathrm{NS} \\
\mathrm{S} \times \mathrm{C}=1.22 \\
\mathrm{~B} \times \mathrm{C}=1.93 \\
\mathrm{~S} \times \mathrm{B} \times \mathrm{C}=2.72\end{array}$} \\
\hline
\end{tabular}

\section{D i s c u s s i o n}

Onion white rot (OWR) is responsible for partially or completely destruction of the bulb yield of Allium crops in Egypt and all over the world (Khaled et al.,1997). The long term use of broad spectrum chemical pesticides has been identified as one of the major causes of environmental pollution and contributes to the deterioration of agricultural land and ecosystem.

Because of biocontrol agents are usually isolated from natural fields, the risk of environmental contamination may be limited but also must be looked upon with great concern. In addition, the bioagents isolated from root zones or rhizosphere soil may colonize the root system and multiply in these rhizospheres (Chao et al., 1986 and Mao et al., 1997), providing long-lasting and long-term effect in minimizing root rots and ensuring healthy plants of the current and the subsequent crops.

The antagonistic ability of eleven bacterial isolates against Sclerotium cepivorum, the causal agent of OWR, was in vitro investigated. The best five isolates were identified according to the cultural properties, morphological, physiological and biochemical characteristics. Results from dual-culture experiment demonstrated that some isolates of Bacillus pumilus and B. marinus significantly reduced the mycelial growth of the pathogen compared with control. 
The antagonistic potential of bacteria ranged from 11.1 to $69.9 \%$. The area of inhibition has in most cases been used as major criteria in the selection of biocontrol agents and has been used as evidence on the production of antifungal secondary metabolites by bacterial strains (Jakson et al.,1991 and Crawford et al., 1993). The reduction in mycelial growth by Bacillus pumilus and B. marinus, selected in this study, might suggest that these bacteria have produced some diffusible inhibitory substances in the medium. Bacillus spp. have been reported to produce a large number of peptide antibiotics and antifungal secondary metabolites representing at least 25 different chemical structures that inhibit mycelial growth of various pathogens by diffusion in culture medium (Mutaz and Hasanain, 2006).

This study demonstrated that 5 Bacillus isolates, i.e. B. pumilus isolate $\mathrm{BP}_{1}$ and $\mathrm{BP}_{2}$ as well as $B$. marinus isolates $\mathrm{BM}_{1}, \mathrm{BM}_{2}$ and $\mathrm{BM}_{3}$, out of 11 tested bacterial isolates provided significant and protection of onion plants against Sclerotium cepivorum under greenhouse and field conditions. The disease was significantly reduced by these bacterial strains with significant increase in bulb yield. In addition, the greenhouse and field tests indicated that the concentration of the bacterial cell suspensions and the number of sprays could affect the biological control results of these bacteria to protect onion plants against $S$. cepivorum. Based on OWR reduction and increase of bulb yield, the $20 \mathrm{ml} / 1$ dose with double sprays seems to be the most effective method of application.

Data showed that applying the tested bacteria at any concentration either once or twice significantly increased bulb yield compared with control treatment during the two growing seasons under field conditions. Generally, it was found that the tested bacteria were more effective in reducing OWR disease in the second growing season compared with the first one. This may be due to differential colonization on onion roots by the tested bacteria and on conditions in the field since survival of the bacteria and the production of antifungal components by these bacteria are greatly affected by soil conditions such as soil type and pH (Schmidt et al., 2004). Previous studies in biocontrol of root rot diseases have demonstrated that the colonization of biocontrol agents at target sites on root system is a prerequisite for suppression of plant pathogen infection (Weller, 1988 and Bull et al., 1991).

In this regard, Edward and Richard (2003) stated that B. pumilus produce an antifungal metabolite that inhibits the growth of Mucoracea and some Aspergillus species including A. flavus, A. fumigatus and A. terreus. Jetiyanon (2007) attributed the efficiency of mixture of Bacillus strains (B. amyloliquefaciens strain IN937a and B. pumilus strain IN937b) to provide systemic protection against multiple diseases in various crops to induction of defense-related enzyme responses. The author found that before inoculation tomato plants with $S$. rolfsii, higher levels of superoxide dismutase and peroxidase activities were observed in plants treated with a mixture of the IN937a and IN937b compared with non-challenged healthy and nonbacterized pathogen controls. Lakesh et al. (2007) indicated that three isolates of B. pumilus (INR-7, SE-34 and T-4) enhanced seed germination and seedling vigor of watermelon to the greatest extent and suppressed seedling diseases caused by broad range of fungal species. Padaria and Aqbal-Singh (2009) reported that B. pumilus MTCC7615 has been identified as a potent isolate against Rhizoctonia solani, the 
cause of sheath blight in rice. They attributed the fungal antagonism of B. pumilus towards $R$. solani to the existence of $23 \mathrm{~kb}$ size $\mathrm{pJCP} 07$ plasmid which found to carry some of the genes involved in the production of a fungal antagonistic compound against Rhizoctonia solani. Sari et al. (2006) verified that induced resistance was another mechanism through which $B$. pumilus $7 \mathrm{~km}$ can suppress wheat take-all disease caused by Gaeumanomyces graminis. Also, this study revealed that B. pumilus $7 \mathrm{~km}$ has plant - promotion activity that affect disease severity. Wheat plants treated with $B$. pumilus $7 \mathrm{~km}$ showed increased presence of soluble peroxidase, cell-wall bound peroxidase, beta-1,3 glucanase, beta -1,4- glucanase and phenolic compounds in bacterized roots challenged with the pathogen. The results suggest that the inhibitory effect of $B$. pumilus $7 \mathrm{~km}$ on take-all disease may be related to its ability to enhance defense response in the wheat roots.

On the other hand, Odile et al. (2003) found that B. marinus was effective in controlling cucumber damping-off caused by Pythium ultimum. Chunmel et al. (2008) isolated a new 24-membere macrolide macrolactin T (1) and a new polyne $\delta$-lactone macrolactin $\mathrm{U}$ (2) along with macrolactins $\mathrm{A}, \mathrm{B}, \mathrm{D}, \mathrm{O}$ and $\mathrm{S}$ from the cultured broth of the bacterium $B$. marinus. They found an inhibitory activity of macrolactins T, B, and D against Alternaria solani and Pyricularia oryzae. The ability of $B$. marinus to control OWR could be attributed to the highest induction activities of phenylalanine ammonialyase (PAL), polyphenol oxidase (PPO) and superoxidase dismutase (SOD). Also, Gao et al. (2010) observed that the fermentation broth of $B$. marinus B-9987 had the highest activity in both fungitoxicity and controlling tomato gray mold and early blight.

It is concluded from this study that using B. pumilus and B. marinus could be a promising treatment to control OWR disease but it should be pointed out that further studies is needed to investigate the main reasons behind the ability of B. pumilus and B. marinus to control OWR disease .

\section{Ref e r e n e s}

Abd El-Magid, M.S. 1994. Studies on some soil-borne fungi affecting garlic plants in A.R.E. Ph.D. Thesis Fac. Agric., Suez Canal Univ. Ismailia, Egypt.

Abd El-Magid, M.S. and Abd El-Momen, S.M. 2008. Biological control of white rot disease in onion. Egypt. J. Appl. Sci., 23(3): 13-23.

Abd El-Moity, T.H. 1981. Further studies on the biological control of white rot disease of onion. Ph.D. Thesis, Faculty of Agric., Menofeia Univ. 135pp.

Anonymous, 2010. Bulletin of the Agricultural Statics. Statistical Dept. of Ministry of Agric. and Soil Reclamation. Agric. Statistics, Winter Crops.

Bull, C.T.; Weller, D.M. and Thomashow, L.S. 1991. Relationship between root colonization and suppression of Gaeumanomyces graminis var. tritici by Pseudomonas fluorescens strain 2-79. Phytopathology, 81: 954-959. 
Chao , W.L.; Nelson, E.B.; Harman, G.E. and Hoch, H.C. 1986. Colonization of the rhizosphere by biological control agents applied to seeds. Phytopathology, 76: $60-65$

Chunmel, X.; Tian, L. Minjuan, X.; Zhiwe, D. and Wenhan, L. 2008. A new 24 -membered lactone and a new polyne $\delta$-lactone from the marine bacterium Bacillus marinus. The Journal of Antibiotics 61: 668-674.

Coley-Smith, J.R. 1990. White rot disease of Allium: Problems of soil-borne diseases in microcosm. Plant Pathol., 39: 214-223.

Crowe, F.J.; Hall, D.H.; Greathead, A.S. and Baghott, K.G. 1980. Inoculum density of Sclerotium cepivorum and the incidence of white rot of onion and garlic. Phytopathology, 70: 64-69.

Crawford, D.L.; Lynch, J.M.; Whips, J.M. and Ousley, M.A. 1993. Isolation and characterization of actinomycetes antagonistic of fungal root pathogen. Appl. Environ. Microbiol. 59: 3899-3909.

De Weger, L.A.; van der Bij, A.J.; Dekkers, L.C.; Simons, M.; Wijffelman, C.A. and Lugtenberg, B.J.J. 1995. Colonization of the rhizosphere of crop plants by plant-beneficial pseudomonads. FEMS Microbiol. Ecol., 17: 221-228.

Edward, J.B. and Richard, W.P. 2003. Production by Bacillus pumilus (MSH) of an antifungal compound that is active against Mucoracea and Aspergillus species: preliminary report. J. Med. Microbial, 52: 69-74.

Entwistle , A.R. 1990a. Root diseases. Pages: 103-154. In: Onion and Allied crops. Agronomy, Biotic Interactions, Pathology and Crop Protection. Vol. II. Rabiowitch, H.D. and Brewster, J.L. (eds.). CRC Press, Boca Raton.

Entwistle, A.R. 1990b. Allium white rot and its control. Soil Use and Management., 6: 201-209.

Fahy, P.C. and Persely, G.J. 1983. Plant Bacterial Diseases: A Diagnostic Guide. Academic Press, London. 393pp.

Fálvia, M.P.; Marli, F.F.; Luiz, A.B.; Maria, E.S.S.; Shirlei, S.; Manoel, A.T. and deMelo, Itamar S. 2009. Antifungal compound produced by the Cassava endophyte Bacillus pumilus MA111M4A. Sci. Agric., 66(5): 583-592.

Fokkema, N.J. 1973. The role of saprophytic fungi in antagonism against Drechslera sorokinana (Helminthsporium sativum) on agar plates and on rye leaves with pollen. Physiol. Plant Pathol., 3: 195-205.

Fravel, D.R. 1988. Role of antibiosis in the biocontrol of plant diseases. Ann. Rev. of Phytopathol., 26: 75-91.

Gao, W.; Tian, L.; Zhang, J.; Zhou, J.; Zheng, L.; Cui, Z. and Li, Y. 2010. A primary study on the biocontrol mechanisms of Bacillus marinus B-9987 against the tomato gray mold and early blight. Plant Protection, 36(1): 55-59. 
Gevlagh, M.; Whipps, J.M.; Budge, S.P. and Goossem-Van de Geijn, H.M. 1996. Efficiency of isolates of Coniothyrium minitans as mycoparasites of Sclerotinia sclerotiorum, Sclerotium cepivorum and Botrytis cinerea on tomato stem pieces. Europ. J. Plant Pathol., 102: 787-793.

Gomez, K.A. and Gomez, A.A. 1984. Statistical Procedures for Agriculture Research. A Wiley-Interscience Pub. NY, USA. 678pp.

Jakson, A.M.; Whips, J.M. and Lynch, J.M. 1991. In vitro screening for identification of potential biocontrol agents of Allium white rot. Mycol. Res., 95: $430-434$.

Jetiyanon, K. 2007. Defensive-related enzyme response in plants treated with a mixture of Bacillus strains ( IN937a and IN937b) against different pathogens. Biological Control, 42(2): 178-208.

Katz, E. and Demain, A.L. 1977. The peptide antibiotics of Bacillus: Chemistry, biogensis and possible functions. Bacteriol. Rev., 41: 449-474.

Khaled, S.A.; Abd El-Sattar, M.A.; Baraka, M.A. and Abd El-Magid, M.S. 1997. Chemical control of garlic soil-borne diseases in Egypt. Egypt. J. Agric. Res., 74(1): 25-34.

Lakesh, S.; Bharath, B.G.; Raghavendra, V.B. and Govindappa, M. 2007. Importance of plant growth-promoting rhizobacteria in enhancing the seed germination and growth of watermelon attacked by fungal pathogens. Acta Agronomica Hungarica, 55(2): 243-249

Lelliot, R.A. and Stead, D.E. 1987. Method for the diagnosis of bacterial diseases of plants. Methods in Plant Pathology. Blackwell Scientific Publications. Oxford, London. 216pp.

Mao, W.; Hebber, J.P. and Lumsden, R. 1997. Seed treatment with fungal or bacterial antagonist for reducing corn damping-off caused by species of Pythium and Fusarium. Plant Dis., 81: 450-454.

Melero-Vara, J.M.; Prados-Ligero, A.M. and Basallote-Ureba, M.J. 2000. Comparison of physical, chemical and biological methods of controlling garlic white rot. Europ. J. Plant Pathol., 106: 581-588.

Mutaz, M.A. and Hasanain, S. 2006. Simple and rapid isolation of a novel antibiotic from Bacillus subtilis Mz-7. J. Liq. Chromatgr. R.T., 29: 639-347

Padaria, J.C. and Aqbal-Singh, A. 2009. Molecular characterization of soil bacteria antagonistic to Rhizoctonia solani sheath blight of rice. J. Environ. Sci. and Health Part B. Pesticides, Food Contaminants and Agric. Wastes, 44(4): 397-402.

Porter, I.J. and Merriman, P.R. 1983. Effects of solarization of soil on nematode and fungal pathogens at two sites in Victoria. Soil Biol. and Biochem., 15: 39-44. 
Odile, C.; Julie, B. and Benhamou, B. 2003. Selection of biological agents from composts for control of damping-off of cucumber caused by Pythium ultimum. Canad. J. Plant Pathol., 25: 258-267.

Sari, E.; Etebarian, H.R.; Roustaei, A. and Aminian, H. 2006. Biological control of Gaeumanomyces graminis on wheat with Bacillus spp. Plant Pathol. J. Faisalabad, 5(3): 307-314.

Satour, M.M.; Rahe, J.E. and Levesque, C.A. 1992. Influence of onion seed bacterization on germination and mycosphere of Sclerotium cepivorum sclerotia. Can. J. Microbiol., 38: 1135-1143.

Sayed, A.M. and Siddiqui, A.Z. 2008. Glomus intraradices, Pseudomonas aclaligenes and Bacillus pumilus: effect agents for the control of root- rot disease complex of chickpea (Cicer arietinum L.). J. Gen. Plant Pathol., 74: 53-60.

Schaad, N.W. 1988. Laboratory Guide for the Identification of Plant Pathogenic Bacteria. $2^{\text {nd }}$ Ed. APS Press, St. Paul, Minnesota, USA.

Schmidt, C.S.; Agotini, F.; Simon, A.M.; Whyte, J.; Townend, J.; Leifert, C.; Killham, K. and Mullins, C. 2004. Influence of soil type and $\mathrm{pH}$ on the colonization of sugar beet seedlings by antagonistic Pseudomonas and Bacillus strains and their control of Pythium damping-off. Europ. J. Plant Pathol., 110: $1025-1046$.

Silva, J.R.C.; deSouza, R.M.; Zacarone, A.B.; deSilva, L.H.C.P. and dos-Castro, A.M. 2008. Control of endophytic bacteria and in vitro inhibition of Pseudomonas syringe pv. tomato, agent of bacterial speck of tomato. Ciencia Agrotechnologia, 32(4): 1062-1072.

Stewart, A.; Kay, S.J. and Fullerton, R.A. 1994a. Biological control of onion white rot in New Zeland. Pages: 102-104. In: Fifth International Workshop on Allium White Rot. Instituto de Agricultura Sostenible, Cordoba

Stewart, A.; Slade, E.A. and Fullerton, R.A. 1994b. Chemical control of onion white rot in New Zeland. Pages: 166-168. In: Fifth International Workshop on Allium White Rot. Instituto de Agricultura Sostenible, Cordoba.

Weller, D.M. 1988. Biological control of soil-borne plant pathogens in the rhizosphere with bacteria. Annu. Rev. Phytopathol., 26: 379-407.

Zhang, J.X.; Xue, A.G. and Tambong, J.T. 2009. Evaluation of seed and soil treatments with novel Bacillus subtilis strains for control of soybean root rot caused by Fusarium oxysporum and F. graminearum. Plant Dis., 93: 1317-1323.

(Received 14/05/2012; in revised form 19/06/2012) 


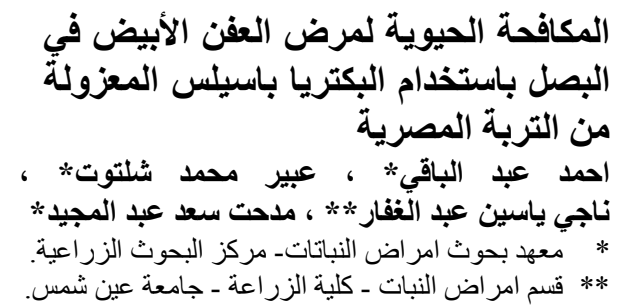

تم تقييم كفاءة القدرة التضادية لاحدي عشرة عزلة بكتيرية ضد ضد الفطر

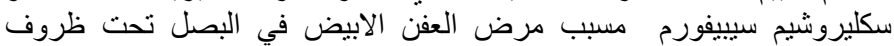

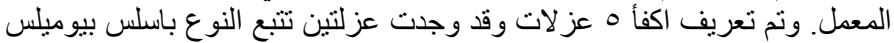

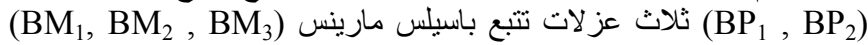

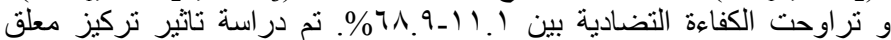

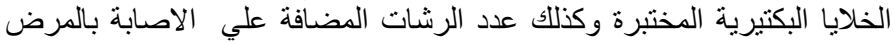

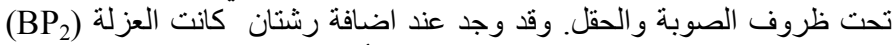

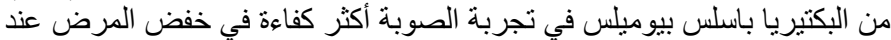

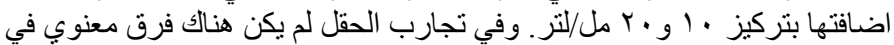

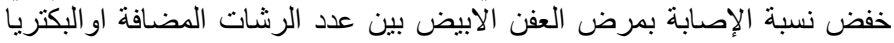

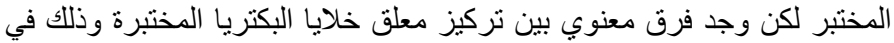

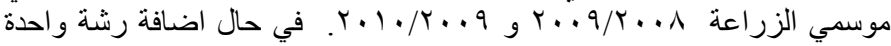

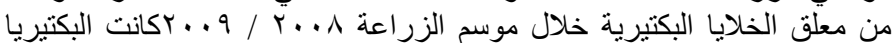

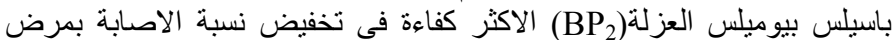

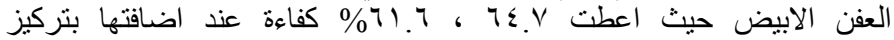

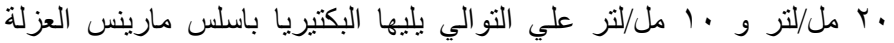

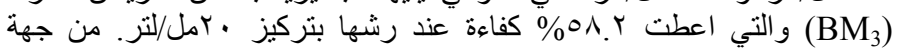

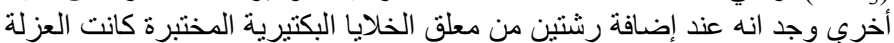
(BM!)

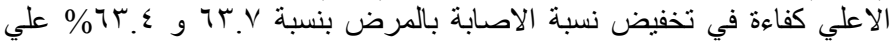

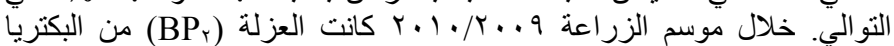

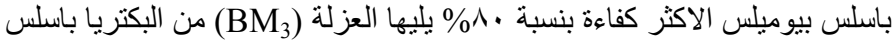

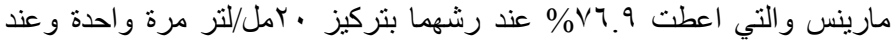

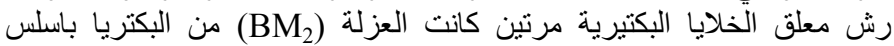

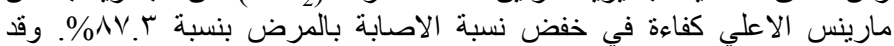

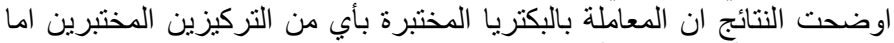

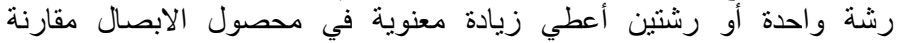

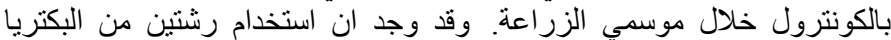

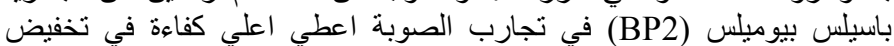

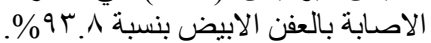

